\title{
Hubungan Kadar Ft4 Dengan Kejadian Tirotoksikosis berdasarkan Penilaian Indeks New Castle Padawanita Dewasa di Daerah Ekses Yodium
}

\author{
Harsa Rusda*, Fadil Oenzil**, Yustini Alioes**
}

Abstrak

Tirotoksikosis merupakan manifestasi klinis yang terjadi akibat peningkatan kadar hormon tiroid dalam darah. Kelebihan yodium merupakan salah satu penyebab terjadinya tirotoksikosis. Ini ditandai dengan hasil pemeriksaan kadar Ekskresi Yodium Urin (EYU) > 199 g/L. Tujuan: Penelitian ini bertujuan untuk mengetahui hubungan kadar FT4 dengan kejadian tirotoksikosis berdasarkan penilaian indeks New Castle pada wanita dewasa di daerah ekses yodium. Metode: Penelitian dilakukan dengan menganalisis data yang dikumpulkan secara Cross Sectional Study terhadap 37 wanita dewasa menggunakan metoda total sampling di Nagari Koto Salak, Kecamatan Koto Salak Kabupaten Dharmasraya yang merupakan daerah ekses yodium (median EYU 323,5 $\mu \mathrm{g} / \mathrm{L}$ ). Pengumpulan data dilakukan dengan wawancara menggunakan penilaian Indeks New Castle dan pengambilan darah untuk dilakukan pemeriksaan kadar FT4 dalam serum. Hasil: Analisis univariat didapatkan jumlah penduduk wanita dewasa dengan kadar FT4 meningkat sebanyak 14 persen dan nilai rata-rata $1,71 \mathrm{ng} / \mathrm{dl}$. Penilaian indeks New Castle dalam kategori doubtful 16 persen dan tidak ditemukan penduduk yang termasuk dalam kategori toxic. Berdasarkan hasil uji statistik Chi-square, didapatkan $p$ value $=1$. Kesimpulan: Tidak terdapat hubungan yang bermakna antara kadar FT4 dalam serum dengan kejadian tirotoksikosis pada wanita dewasa di derah ekses yodium. Saran: Perlu dilakukan penyuluhan mengenai asupan yodium kepada masyarakat dan diharapkan penelitian ini dapat menjadi masukan kepada pemerintah dalam mengambil kebijakan terhadap pemberian kapsul yodium serta melakukan kontrol kadar EYU secara teratur dan berkala.

Kata kunci: FT4, tirotoksikosis, indeks New Castle, wanita, ekses yodium, tiroid

\begin{abstract}
Thyrotoxicosis is a clinical manifestation that occurs due to elevated levels of thyroid hormones in the blood. lodine excess is one of the causes of thyrotoxicosis. This is indicated by the results of urine iodine excretion levels $(E Y U)>199 \mu \mathrm{g} / \mathrm{L}$. Objective: This study aimed to determine the association FT4 levels with thyrotoxicosis incidence based on New Castle index assessment of adult women in iodine excess area.Method: The study was conducted data analysis which collected with Cross Sectional Study against 37 adult females by using total sampling methods in Koto Salak. Dharmasraya regency which is the iodine excess area (median EYU 323,5 $\mu \mathrm{g} / \mathrm{L}$ ). Data were collected by using interview New Castle Index assessments and blood sampling for examination FT4 levels in blood serum. Result: Univariate analysis of adult women population is 14 percent in increase category of FT4 levels and 1,71 $\mathrm{ng} / \mathrm{dl}$ of the average value. New Castle index assessment 16 percent in doubtful category and none included in the toxic category. Based on Chi-Square statistics test, showed $p$ value=1. Conclution: There was no significant association between FT4 levels in blood serum with thyrotoxicosis incidence of adult women in iodine excess area.Suggestion: Therefore, it should be informed to the community about iodine intake and this research is hoped can be input for the government policy towards iodine suplementation and control EYU levels regularly and periodically.
\end{abstract}

Keywords: FT4, thyrotoxicosis, New Castle index, women, iodine excess, thyroid

Affiliasi penulis : Harsa Rusda

Korespondensi : Fakultas Kedokteran Universitas Andalas, email : harsa_rusda1@yahoo.co.id, Telp/Hp : 085274074606

\section{PENDAHULUAN}

Penyakit kelenjar tiroid (kelenjar gondok) termasuk penyakit yang sering ditemukan di masyarakat. Hipertiroid merupakan salah satu penyebab penyakit kelenjar tiroid, ini merupakan penyakit hormon yang menempati urutan kedua terbesar di Indonesia setelah diabetes. ${ }^{1}$

Berdasarkan hasil pemeriksaan ekskresi yodium dalam urin (EYU) tahun 2008, skala nagari se Propinsi Sumatera Barat, didapatkan hasil median EYU $102 \mu \mathrm{g} / \mathrm{L}$. Data tersebut menggambarkan secara umum masyarakat di Provinsi Sumatera Barat telah mencapai kecukupan asupan yodium termasuk dalam kriteria optimum. Sumatera Barat bukan termasuk daerah endemik, tetapi analisis dengan skala lebih kecil yaitu kabupaten, kecamatan, dan nagari perlu dilakukan penelitian untuk mengetahui adanya daerah kantong endemik. Median EYU berdasarkan nagari didapatkan satu daerah dengan ekses yodium berat (EksiB) yaitu pada Nagari Koto Salak, Kecamatan Koto Salak, Kabupaten Dharmasraya. ${ }^{2}$ Berdasarkan data Dinas Kesehatan Propinsi Sumatra Barat tahun 2009, tercatat 49 dari 52 desa di Kabupaten Dharmasraya merupakan daerah dengan konsumsi garam beryodium yang baik, dengan persentase secara keseluruhan 94,23 persen. ${ }^{3}$

Beberapa keadaan klinis dapat terjadi akibat gangguan pada kelenjar tiroid, salah satunya adalah 
tirotoksikosis. Tirotoksikosis merupakan manifestasi klinis yang terjadi akibat peningkatan kadar hormon tiroid dalam darah. Tirotoksikosis digunakan untuk menandai temuan klinis, fisiologi, dan biokimia yang dihasilkan saat jaringan terpajan dan memberikan respon terhadap hormon berlebihan. ${ }^{4,5}$ Penyakit ini dapat terjadi pada berbagai usia, namun lebih banyak terjadi pada usia 40-50 tahun. ${ }^{6,5}$ Berdasarkan data tahun 2000 , dua persen wanita dan 0,2 persen laki-laki menderita penyakit ini di dunia.

Ekses yodium merupakan penyebab terjadinya tirotoksikosis. Ini dapat menyebabkan aktivitas tiroid menjadi tidak terkontrol, hal ini dikarenakan, jumlah yodium yang berlebihan dapat memblok fungsi tiroid dalam membuat hormon. Ini meningkatkan risiko $\mathrm{IIH}$ (lodine Induced Hiperthyroidsm). ${ }^{8}$

Di dalam darah, sebagian besar hormon T4 dan T3 terikat oleh protein dan bersifat tidak aktif. Satu persen berada dalam bentuk bebas (free) sehingga disebut FT4 dan FT3, yang aktif mengendalikan metabolisme tubuh. Pengukuran hormon tiroid total (T4 total atau T3 total) atau bentuk bebas (FT4 atau FT3) biasanya memberikan informasi yang sama, sehingga tidak perlu diperiksa sekaligus. ${ }^{6}$

Gejala klinis yang didapatkan akibat sekresi hormon tiroid yang berlebihan, diantaranya: meningkatnya laju metabolik, rasa cemas yang berlebihan, meningkatnya nafsu makan tetapi berat badan menurun, gerakan yang berlebihan, gelisah dan instabilitas emosi, penonjolan pada bola mata, dan tremor halus pada jari tangan. Salah satu pemeriksaan yang dapat digunakan adalah dengan menggunakan indeks New Castle yang didasarkan anamnesis dan pemeriksaan fisik yang teliti, kemudian diteruskan dengan pemeriksaan penunjang untuk konfirmasi diagnosis anatomis, status tiroid, dan etiologi. ${ }^{5}$

Mengingat sangat beragamnya gejala yang dapat ditimbulkan karena kelebihan asupan yodium, maka peneliti tertarik untuk melakukan penelitian mengenai sejauh mana peningkatan kadar FT4 dan bagaimana hubungannya dengan kejadian tirotoksikosis pada wanita dewasa di daerah ekses yodium.

Penelitian ini bertujuan untuk mengetahui hubungan kadar hormon FT4 dengan kejadian tirotoksikosis pada wanita dewasa di daerah ekses yodium yaitu di Nagari Koto Salak Kabupaten Dharmasraya.

\section{METODE PENELITIAN}

Penelitian ini merupakan penelitian analitik dengan menggunakan pendekatan Cross Sectional. Hal ini dikarenakan data yang dikumpul dan variabel yang diteliti hanya diukur satu kali dalam waktu yang bersamaan. ${ }^{9,10}$ Penelitian ini dilaksanakan di Nagari Koto Salak, Kecamatan Koto Salak, Kabupaten Dharmasraya yang merupakan daerah ekses yodium urin $(E Y U=323,5)$. Pemeriksaan kadar FT4 dalam serum darah dilakukan di Balai Laboratorium Kesehatan Sumatera Barat. Populasi penelitian ini adalah semua wanita di Nagari Koto Salak Kabupaten Dharmasraya yang datang untuk melakukan pemeriksaan dan pengisian kuesioner. Seluruh populasi dijadikan subjek penelitian. Kriteria Subjek penelitian: yaitu kriteria Inklusi : Berusia 18-65 tahun, bertempat tinggal di Nagari Koto Salak Kabupaten Dharmasraya, dan bersedia ikut dalam penelitian dengan menandatangani inform consent. Kriteria
Eksklusi yaitu hasil pemeriksaan yang tidak dapat diukur. Penelitian ini menggunakan kuesioner dari Indeks New Castle dan alat Immuno Auto Analyzer (cobas e 411, spesifikasi full automatic). Variabel penelitian: variabel bebas=FT4, variabel terikat=tirotoksikosis. Data yang diperoleh dari hasil pemeriksaan terhadap serum darah dan indeks diagnostik New Castle. Pengolahan dan analisa data dilakukan secara komputerisasi dengan menggunakan pengujian statistik Chi-Square dengan derajat bermakna $\alpha=0,05 .^{11}$

\section{HASIL PENELITIAN}

Berdasarkan hasil penelitian yang dilakukan terhadap 46 orang wanita dewasa di Nagari Koto Salak Kabupaten Dharmasraya, didapatkan 37 orang yang memenuhi syarat untuk dilakukan penelitian.

\section{Analisa Univariat}

Tabel 1. Distribusi frekuensi hasil pemeriksaan FT4

\begin{tabular}{lcc}
\hline \multicolumn{1}{c}{ FT4 (ng/dl) } & Frekuensi & $\begin{array}{c}\text { Persentase } \\
(\%)\end{array}$ \\
\hline $\begin{array}{l}\text { Normal }(0,93-1,7 \\
\text { ng/dl) }\end{array}$ & 32 & 86 \\
$\begin{array}{l}\text { Meningkat }(>1,7 \\
\text { ng/dl) }\end{array}$ & 5 & 14 \\
$\begin{array}{l}\text { Menurun }(<0,93 \\
\text { ng/dl) }\end{array}$ & 0 & 0 \\
$\begin{array}{l}\text { Jumlah } \\
\text { Maksimum = }\end{array}$ & $37,7 \mathrm{ng} / \mathrm{dl}$ \\
$\begin{array}{l}\text { Minimum }=0,973 \mathrm{ng} / \mathrm{dl} \\
\text { Rata-rata }=1,71 \mathrm{ng} / \mathrm{dl}\end{array}$ & 100 \\
\hline
\end{tabular}

Dari 37 orang yang telah diperiksa kadar hormon FT4 didapatkan hasil, 32 orang dengan hasil pemeriksaan normal dengan persentase tertinggi yaitu 86 persen. Lima orang dengan kadar FT4 yang meningkat dengan frekuensi 14 persen. Dan tidak ada subjek penelitian yang memiliki kadar FT4 rendah. Kadar FT4 tertinggi yang diperoleh adalah $7,7 \mathrm{ng} / \mathrm{dl}$, kadar FT4 terendah adalah $0,973 \mathrm{ng} / \mathrm{dl}$, dan kadar rata-rata adalah $1,71 \mathrm{ng} / \mathrm{dl}$

Tabel 2. Distribusi frekuensi hasil wawancara berdasarkan penilaian Indeks New Castle

\begin{tabular}{lcc}
\hline Indeks New Castle & Frekuensi & $\begin{array}{c}\text { Persentas } \\
\mathbf{e}\end{array}$ \\
\hline Euthyroid $(-11$ to +23$)$ & 31 & 84 \\
Doubtful $(+24$ to +39$)$ & 6 & 16 \\
Toxic $(+40$ to +80$)$ & 0 & 0 \\
Jumlah & 37 & 100 \\
Maksimum $=35$ & & \\
Minimum $=-11$ & & \\
\hline
\end{tabular}

Berdasarkan tabel 2, didapatkan hasil 31 orang (84 persen) dalam batas normal. Enam orang dalam kategori meragukan dengan persentase 16 persen. Tidak ada yang memiliki skor lebih dari 40 yang termasuk ke dalam kategori toxic. Dari data yang didapatkan, tidak ada yang menderita tirotoksikosis. Skor tertinggi yang diperoleh dari hasil wawancara adalah 35 dan terendah -11 . 


\section{Analisa Bivariate}

Tabel 3. Hubungan kadar FT4 dengan hasil wawancara Indeks New Castle

\begin{tabular}{lccccccc}
\hline & \multicolumn{3}{c}{ Indeks New Castle } & \multicolumn{3}{c}{ Total } & $\%$ \\
\cline { 2 - 5 } \multicolumn{1}{c}{ FT4 } & Euthyroid & $\%$ & Doubtful & $\%$ & & \\
\hline Normal & 27 & 73 & 5 & 13,5 & 32 & 86,5 \\
Meningkat & 4 & 10,8 & 1 & 2,7 & 5 & 13,5 \\
Total & 31 & 83,8 & 6 & 16,2 & 37 & 100 \\
\hline $\mathrm{X}^{2}$ hitung $=3,841$ & & & & & $\mathrm{df}=1$ \\
$\mathrm{p}$ value $=1$ & & & & & &
\end{tabular}

Analisis data dengan tabel bivariate bertujuan untuk melihat hubungan kadar FT4 dengan hasil pemeriksaan menggunakan Indeks New Castle. Dari tabel diatas terlihat bahwa 27 orang mempunyai kadar FT4 dalam batas normal dengan hasil wawancara dalam kategori euthyroid dengan persentase 73 persen. Empat orang memiliki kadar FT4 yang meningkat dengan skor indeks New Castle euthyroid dengan persentase 10,8 persen, lima orang memiliki kadar FT4 normal dengan skor Indeks New Castle dalam kategori doubtful (meragukan) dengan persentase 13,5 persen, dan satu orang memiliki kadar FT4 yang meningkat dengan skor Indeks New Castle dalam kategori doubtful (meragukan) dengan persentase 2,7 persen.

Analisa untuk mengetahui hubungan kedua variabel tersebut yaitu dengan menggunakan metoda Chi-Square. ${ }^{12}$ Analisis bivariat menggunaan analisis Chi-Square dengan $\mathrm{df}=1 \quad \alpha=0,05$ didapatkan nilai $\mathrm{p}$ value $=1$

Berdasarkan hasil analisis, didapatkan hasil $p$ value $(1)>\alpha(0,05)$, maka dapat disimpulkan bahwa tidak terdapat hubungan yang bermakna antara kadar FT4 dengan hasil wawancara menggunakan penilaian indeks New Castle.

\section{PEMBAHASAN}

\section{Kadar FT4 Serum}

Pemeriksaan kadar FT4 yang dilakukan di laboratorium kesehatan provinsi Sumatera Barat, didapatkan hasil 32 orang (86 persen) dengan hasil pemeriksaan FT4 normal, 5 orang (14 persen) dengan hasil pemeriksaan FT4 meningkat, dan tidak ada yang memiliki kadar FT4 rendah. Kadar rata-rata FT4 yang didapatkan dari hasil pemeriksaan adalah $1,71 \mathrm{ng} / \mathrm{dl}$ dengan kadar tertinggi $7,7 \mathrm{ng} / \mathrm{dl}$ dan terendah 0,973 $\mathrm{ng} / \mathrm{dl}$. Berdasarkan tabel distribusi frekuensi hasil pemeriksaan FT4, kadar rata-rata yang didapatkan ini termasuk dalam kategori meningkat karena lebih dari $1,7 \mathrm{ng} / \mathrm{dl}$.

Hal ini menunjukkan penduduk daerah ini telah mengalami peningkatan kadar hormon tiroid di dalam darahnya. Sesuai dengan teori, kadar FT4 dikatakan meningkat jika hasil yang didapatkan lebih dari 1,7 ng/dl. Ini menunjukkan penderita mengalami tirotoksikosis. Sebaliknya kadar FT4 yang rendah menandakan penderita mengalami hipotiroidisme disebabkan oleh kegagalan kelenjar tiroid. Proses apapun yang menyebabkan peningkatan hormon tiroid bebas dalam sirkulasi akan menimbulkan tanda dan gejala hipertiroidisme. Gangguan mekanisme homeostasis dapat terjadi pada tingkat pituitary, kelenjar tiroid atau perifer. Kadar FT4 sangat berkorelasi dengan gambaran klinis yang ditimbulkan. ${ }^{13}$ Salah satu penyebab peningkatan ini karena tingginya asupan yodium yang dikonsumsi masyarakat. Asupan yodium ini tergambar dari hasil pemeriksaan ekskresi yodium urin (EYU). ${ }^{14}$

Kadar rata-rata yodium dalam urin pada survei evaluasi tahun 2003 pada tingkat propinsi didapatkan kadar tertinggi $337 \mu \mathrm{g} / \mathrm{dl}$, dan sebanyak 35 persen masuk kategori risiko kelebihan yodium (yaitu $>300 \mu \mathrm{g} / \mathrm{dl}$ ). Hal ini menunjukkan bahwa munculnya penyakit tirotoksikosis perlu diwaspadai seiring dengan penanggulangan GAKY dengan pemberian kapsul beryodium. Pada penelitian ekskresi yodium urin pada tahun 2003 pada tingkat kabupaten kota, ditemukan banyak yang mempunyai nilai median EYU diatas normal yaitu menjadi 66,8 persen dibandingkan penelitian sebelumnya pada tahun 1998 yang hanya 24,4 persen. Ini berarti sebagian penduduk memiliki status yodium yang dapat meninmbulkan gangguan kesehatan dan mempengaruhi aktivitas kerja seharihari. $^{15}$

Berdasarkan laporan EYU skala nagari se Provinsi Sumatera Barat dengan pengambilan sampel dari seluruh wilayah di Provinsi Sumatera Barat, didapatkan hasil, nagari Koto Salak dengan median EYU 323,5 $\mu \mathrm{g} / \mathrm{L}$ termasuk dalam kategori ekses berat dan merupakan satu-satunya daerah di Sumatera barat dengan kategori tersebut. Penelitian dilakukan terhadap wanita usia subur dengan pengambikan 20 sampel dari masing-masing nagari.

Sesuai dengan teori, asupan yodium yang berlebihan dapat memblok fungsi tiroid dalam menyekresikan hormon dan menyebabkan aktivitas tiroid menjadi tidak terkontrol. Hal ini merupakan penyebab terjadinya tirotoksikosis. Median EYU 200$299 \mu \mathrm{g} / \mathrm{L}$ sudah dikatakan melebihi kecukupan dan dapat menimbulkan resiko hipertiroid dalam 5-10 tahun. Bila median EYU $>300 \mu \mathrm{g} / \mathrm{L}$, ini sudah merupakan kelebihan asupan yodium dan memiliki resiko untuk timbulnya gangguan kesehatan (iodineinduced hypertiroidism, autoimmune thyroid disease). ${ }^{8}$ Dapat disimpulkan bahwa kelebihan asupan yodium ini menyebabkan fungsi otonom dari tiroid mensintesis dan melepaskan hormon tiroid dalam jumlah yang berlebihan. Ini ditandai dengan peningkatan kadar hormon tiroid dalam darah terutama kadar hormon FT4. Kelebihan yodium ini juga dapat berakibat buruk terhadap kesehatan yaitu terjadinya tirotoksikosis. Penyebab median EYU yang tinggi memerlukan perhatian khusus dari pemerintah yaitu dengan melakukan evaluasi asupan yodium penduduk secara berkala dengan memperhitungkan juga sumber yodium selain dari garam beryodium seperti pemberian kapsul yodium.

\section{Indeks diagnostik New Castle}

Indeks Diagnostik New Castle merupakan suatu checklist yang berisi ada atau tidaknya gejala dan tanda dengan skor tersendiri. Berdasarkan hasil wawancara yang dilakukan kepada 37 wanita dewasa di Nagari Koto Salak Kabupaten Dharmasraya, didapatkan hasil tertinggi dengan skor 35 dan terendah dengan skor -11 . Berdasarkan kategori yang telah ditentukan, 31 orang ( 84 persen) dalam batas normal, 6 orang (16 persen) dengan kategori doubtful (meragukan), dan tidak ada yang memiliki skor lebih dari 40 yang merupakan kategori toxic. Ini berarti tidak ada subjek penelitian yang mengalami tirotoksikosis.

Hal ini sesuai dengan teori, untuk menegakkan diagnosis tirotoksikosis berdasarkan keluhan serta tanda-tanda klinis yang dijumpai dapat digunakan indeks New Castle. Gejala klinis utama dari tirotoksikosis adalah dijumpainya keluhan 
berdebar, gelisah, berkeringat, tidak tahan cuaca panas. Pada pemeriksaan fisik sering ditemukan adanya takikardi, penurunan berat badan walaupun nafsu makan meningkat, menurunya gerakan kelopak mata, tremor halus dan kelemahan otot. Pada sistem saraf pusat, tirotoksikosis dapat menimbulkan manifestasi klinis berupa peningkatan sistem saraf simpatis berupa kegelisahan, tremor, dan tekikardi. Efek metabolik dari tirotoksikosis mempengaruhi semua sistem organ. Peningkatan hormon tiroid dalam keadaan berlebih menyebabkan peningkatan laju metabolisme yang merupakan tanda-tanda klinis tirotoksikosis. ${ }^{16}$

Berdasarkan hasil pemeriksaan didapatkan hasil 16 persen dengan kategori doubtful (meragukan). Sesuai dengan teori, ini mengindikasikan daerah tersebut termasuk subklinis. Pada kasus ini, pemeriksaan FT4 diperlukan untuk menegakkan diagnosis. Diagnosis tirotoksikosis ditegakkan bila terdapat tanda-tanda klinis disertai peningkatan kadar hormon tiroid. ${ }^{17}$

\section{Hubungan kadar FT4 dengan Kejadian Tirotoksikosis}

Pemeriksaan kadar FT4 dalam darah dan wawancara menggunakan indeks New Castle merupakan pemeriksaan yang diperlukan untuk menegakkan diagnosis tirotoksikosis. Berdasarkan hasil analisis statistik yang dilakukan, didapatkan nilai $p$ value $(1)<$ $\propto(0,05)$. Ini menjelaskan bahwa tidak terdapat hubungan yang bermakna antara kedua variabel penelitian. Tidak ditemukannya subjek penelitian yang merupakan penderita tirotoksikosis, tetapi dengan ditemukannya beberapa orang yang termasuk dalam kategori doubtful (meragukan), ini menandakan daerah ini merupakan daerah subklinik. Hal ini diperkuat lagi dengan didapatkan peningkatan kadar FT4 serum pada penduduk yang dilakukan penelitian. Sesuai dengan teori, Subklinik hypertiroidisme jika kadar TSH rendah $(<0,5 \mathrm{mIU} / \mathrm{L}$, konsentrasi $\mathrm{FT} 4$ normal atau meningkat dengan sedikit atau tanpa gejala klinis. $^{18}$ Keadaan ini mencerminkan adanya pengurangan produksi dan sekresi TSH sebgai respon terhadap peningkatan ringan hormon tiroid yang masih dalam rentang subklinis. ${ }^{14}$

Prevalensi hipertiroid subklinis di masyarakat berkisar antara 0,7-12,4 persen. Pada peelitian National Health and Nutrition Examination Survey (NHANES IV) didapatkan angka 0,7 persen dari 16.533 orang yang mengalami hipertiroid subklinis. ${ }^{19}$

Hipertiroid Subklinis penyebabnya dibedakan menjadi dua faktor yaitu faktor endogen dan eksogen. Faktor eksogen merupakan penyebab terbanyak. ${ }^{(20)}$ Kelebihan asupan yodium merupakan salah satu faktor eksogen. Pemberian kapsul yodium diduga sebagai penyebab meningkatnya kejadian ini. Sebanyak 10 juta penduduk Amerika Serikat mengalami hipertiroid subklinis disebabkan faktor eksogen dan sebanyak dua juta penduduk dunia mendapatkan terapi hormon tiroid yang merupakan faktor risiko terjadinya tirotoksikosis. Hipertiroid subklinis merupakan suatu terminologi yang secara klinis gejalanya tidak nyata, disebabkan kegagalan fungsi tiroid minimal. Untuk konfirmasi diagnosis, diperlukan pemeriksaan laboratorium yang berkaitan dengan fungsi kelenjar tiroid. ${ }^{19}$

$\mathrm{Hal}$ ini perlu mendapat perhatian khusus dari pemerintah terhadap penduduk dalam hal evaluasi asupan yodium dalam hal pemberian kapsul yodium dengan melakukan kontrol kadar EYU secara teratur dan berkala.

\section{Kesimpulan}

1. Jumlah penduduk wanita dewasa di Nagari Koto Salak dengan kadar FT4 meningkat sebanyak 14 persen dan nilai rata-rata 1,71 $\mathrm{ng} / \mathrm{dl}$.

2. Wawancara menggunakan penilaian indeks diagnostik New Castle didapatkan hasil 16 persen dalam kategori doubtful (meragukan) dan tidak ditemukan penduduk yang termasuk dalam kategori toxic

3. Tidak terdapat hubungan yang bermakna antara kadar FT4 dalam serum dengan kejadian tirotoksikosis pada wanita dewasa di daerah ekses yodium.

\section{Daftar Pustaka}

1. Minaoki, Andika, 2011. Hipertiroid. Diakses dari http://www.indoroyal.com/infomedis/hipertiroid.html (17 Februari 2012).

2. Dinas Kesehatan Propinsi Sumatera Barat. Evaluasi Program Gondok. 2009.

3. Widodo, U.S. Laporan Hasil Pemeriksaan Ekskresi Yodium dalam Skala Nagari se Propinsi Sumatera Barat. Jayan, Borobudur, Magelang: Balai Penelitian Gangguan Akibat Kekurangan Yodium. 2008.

4. Ganong, W.F. Review of Medical Physiology, $17^{\text {th }}$ ed. Buku Ajar Fisiologi Kedokteran. Jakarta: EGC. 1998. hlm 322-327.

5. Djokomoeljanto, R.. Kelenjar Tiroid, Hipotiroidisme, dan Hipertiroidisme. Dalam : Sudoyo A.W. et al, eds. Buku Ajar IImu Penyakit Dalam Jilid III Edisi V. Jakarta Pusat: Pusat Penerbitan IImu Penyakit Dalam. 2009. hlm 1993-2015.

6. Semiardji, Gatut. Penyakit Kelenjar Tiroid: Gejala Diagnosis dan Pengobatan. Jakarta: Balai Penerbit FKUI. 2008. hlm 1-37.

7. Sutjanto, Ari, ed. Seri-1 Endokrin-Metabolik Kapita Selekta Tiroidologi. Surabaya: Airlangga University Press. 2010. hlm 63-73.

8. WHO/UNICEF/ICCIDD. 2012. FAQs about lodine Nutrition. Diakses dari http://www.iccidd.org/pages/iodinedeficiency/faqs.php (21 Februari 2012).

9. Natoatmodjo, Soekidjo. Metode Penelitian Kesehatan. Jakarta: Rineka Cipta. 2010. hlm 75-89.

10. Sastroasmoro, Sudigdo dan Ismael, Sofyan. Dasar-Dasar Metode Penelitian Klinis, edisi 4. Jakarta: Sagung Seto. 2011. hlm 130-145.

11. Chandra, B. Metodologi Penelitian Kesehatan. Jakarta: EGC. 2008

12. Trihendradi, C. 7 Langkah Mudah Melakukan Analisa Statistik Menggunakan SPSS 17. Yogyakarta: ANDI. 2009. hlm 77-84.

13. Schraga, ED. 2012. Hyperthyroidsm, Thyroid Storm and Graves Disease. Medscape. Available at $\mathrm{http}: / /$ emedicine.medscape.com.

14. Suryaatmadja, Marzuki. 2010. Tiroid: Pemeriksaan Laboratorium. Diakses dari http://www.info@abclab.co.id (17 Januari 2013).

15. Suparyatno. 2011. Gangguan Akibat Kekurangan Yodium. Diakses dari 
http://www.suparyatno.blogspot.com

$(30$

Januari 2013)

16. Ginsberg, Jody. Diagnosis and management of Graves' disease. Canadian Medical Association Journal. 2003;16:575-85.

17. Pranoto, Agung. 2006. Seorang penderita tirotoksikosis dengan periodik paralisis. Diakses dari http://www.penelitian.unair.ac.id tanggal 19 Januari 2013.

18. Shrier, Diane K, Kenneth D. Burman. Subclinical Hyperthyroidms : Controversies in Management. American Family Physician Journal. 2002;65(3):431-437.
19. Ross, DS. 2005. Subclinical Hyperthyroidsm. In: $2^{\text {nd }}$ nd Joint SPED/AACE International Endocrine Clinical Uptake and $28^{\text {th }}$ SPED Post Graduate Diabetes Course, Desember 2005. San Juan. Puerto Rico.

20. Hoogendoorn EH, Heijer MD, Van Dijk APJ, Heirmus AR. Subclinical Hyperthyroidsm: to Treat or Not to Treat. Postgrad Medical Journal. 2004;80:394-8. 